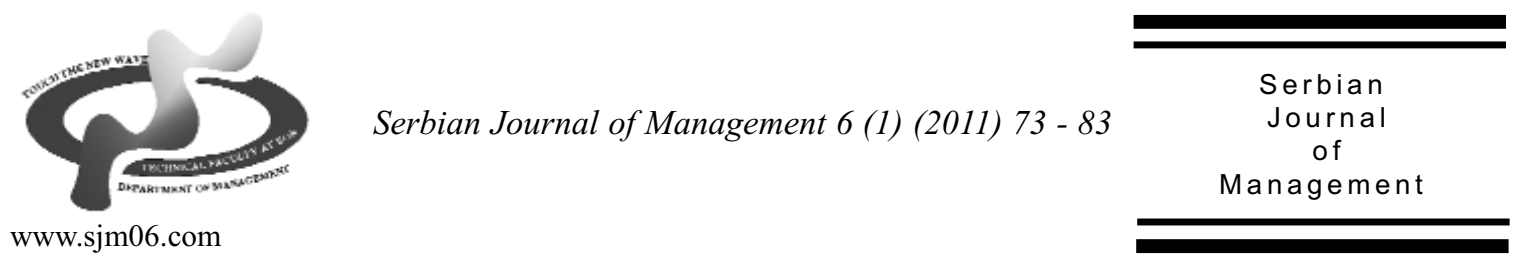

\title{
ENTREPRENEURS' MOTIVATIONAL FACTORS: EMPIRICAL EVIDENCE FROM SERBIA
}

\author{
Ivan Stefanovića ${ }^{*}$, Ljubodrag Rankovićb and Sloboda Prokićc

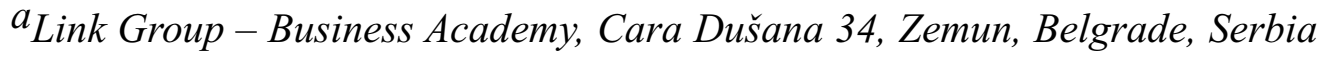

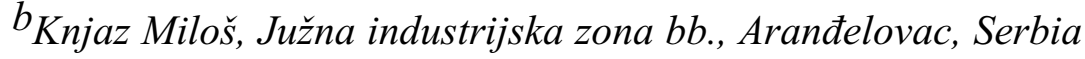 \\ ${ }^{c}$ Serbian Economic Centre, Brankova 30, Belgrade, Serbia
}

(Received 11 October 2010; accepted 10 January 2011)

\begin{abstract}
Entrepreneurs are playing a major role in the economy of each country on the planet. They contribute to national economies by starting up and running small and medium sized enterprises (SMEs), which make more than $95 \%$ of the total number of enterprises and which are providing jobs to more than $60 \%$ of all employees within each country. The significance of entrepreneurship for economic development oblige goverments and all other relevant institutions within each country to continue to facilitate its growth by all means necessary. In order to do this, these institutions need to be familiar with motives of entrepreneurs to start their own business. In this paper, results of empirical research concerning motivational factors of entrepreneurs in Serbia are presented. This research presents a continuation of serie of research on this topic which were conducted in several countries, by using the same methodological approach.
\end{abstract}

Keywords: Entrepreneur, SME, motivation, factor, analysis

\section{INTRODUCTION}

The emergence and development of entrepreneurship is an important phenomenon in contemporary economies. Entrepreneurship is strongly linked to small and medium sized enterprises (SMEs), which are the main developing force of the developed market economies. SMEs are usually representing the majority of all the enterprises and accordingly they are main driving force of entrepreneurship development and economy. In most of developed countries, percentage of SMEs in

\footnotetext{
*Corresponding author:stefanovic@sbb.rs
} 
total number of enterprises is around 90\%, while $60 \%$ of available workforce is employed in those firms.

SMEs stimulate initiative, invention and overall entrepreneurial spirit. Their specificities enable them to be far more flexible then large enterprises, which is one of the basic conditions for adaptability to environmental shifts. These are only some of the reasons resulting with large number of SMEs existing in all developed economies, which advocate the fact of their extremely importance (Stefanović, Milošević \& Miletić, 2009).

Nevertheless, numerous investigations show that Europeans, in general, express tendencies rather to work in some firm (for someone else) then to start their own business (Jones \& Nummela 2008). This tendency is typical for postcomunist countries, in which the longlasting easiness of working in a state-owned firm has become dominant determinant in human behavior (Jiangyong \& Tao, 2008).

In Serbia, which is a developing country, which is going through a process of economic transition, SMEs also represent a vast majority of enterprises. Thus, the importance of SMEs for entire Serbian economy is very large with the tendency of further increase in its importance.

Because of the great importance of entrepreneurs and SMEs for developing economies, this research addresses motivational factors of entrepreneurs in Serbia, and can be considered as research guidelines for scholars in other developing countries. Understanding these factors can be helpful for entrepreneurs and their SMEs, because it could affect the increase of percentage of successful ventures.

\section{THEORETICAL BACKGROUND}

Importance of entrepreneurship and SMEs development for long-term economic growth is quite obvious. For example, in European Union (EU-27), SMEs account for $99.8 \%$ of all enterprises, out of which the vast majority of enterprises are micro enterprises (they comprise $91.8 \%$ of all enterprises). SMEs provide jobs to $67.1 \%$ of all employees and participate with $57.6 \%$ of total added value (Schmiemann, 2008).

In order to continue analysing entrepreneurship, we must first closely look at the very notion of the terms: "entrepreneurship" and "entrepreneur". Thus, entrepreneurship can be viewed as the formation of a new firm that uses innovation to enter existing markets (or to create new ones) and grow by making new demand, while taking market share away from existing suppliers (Schumpeter, 1934). On the other hand, entrepreneur is someone who independently owns and actively manages a small business (Collins, Hanges \& Locke 2004). Entrepreneur is someone who introduces new ideas and changes the rate at which the wheels of enterprise go around (Evans, 1942). Talented persons should be particularly ecouraged to become entrepreneurs, for it is these who will contribute most to the creation of labour demand (van Praag \& Cramer, 2001) and the economy growth.

Considering that these men and women are very significant for the growth and development of economies in countries in which they operate their businesses, understanding their motivational factors is a very important topic. These two groups of factors have a considerable impact on development of entrepreneurial activities and on birth rate and growth of SMEs. 
Unforunately, studies on this topic were not conducted in satisfying amount in the developing countries, especially in Serbia, until recently (Živković, Mihajlović \& Prvulović, 2009; Živković \& Živković, 2009).

Impact of entrepreneurs' motivation on their success is a widely known topic. A number of studies was conducted to determine this relationship. Kuratko, Hornsby and Naffziger (1997) and Robichaud, McGraw and Roger (2001) surveyed entrepreneurs from North America to determine what motivation categories lead to business success. Findings from their studies show that motivation of entrepreneurs falls into four distinct categories: 1. extrinsic rewards, 2. independence/autonomy, 3. intrinsic rewards and 4. family security. These four group of factors determine the motivation level of entrepreneurs which in turn affects on their business success.

Benzing, Chu and Kara (2009) in their study of entrepreneurs in Turkey, among other things, presented a comparative results of numerous research on entrepreneurs' motivating factors in different countries. For example, they stated that Swierczek and $\mathrm{Ha}$ (2003) in their study of Vietnamese small business owners found that challenge and achievement were more significant motivators than necessity and security. In Romania, income and job security needs were stronger motivators than selfsatisfaction and personal needs (Benzing, Chu \& Szabo 2005). On the other hand, entrepreneurs in India were most strongly motivated by the desire for autonomy and then to increase their income (Benzing \& Chu 2005). In Turkey, entrepreneurs are motivated to start their own business so they could provide security for themselves and their family and to increase income (Ozsoy, Oksoy \& Kozan 2001). Benzing, Chu and Kara (2009) also presented research results from African countries. Ugandan entrepreneurs are motivated by "making money" (Bewayo 1995). A study of entrepreneurs in Kenya and Ghana (Chu, Benzing \& McGee 2007) found that the strongest two motivators were to increase income and to provide employment to themselves. Roy and Wheeler (2006) found that microenterprise owners in West Africa were motivated by a desire to satisfy basic psychological needs - food and shelter.

One survey, which was focused on nascent entrepreneurs, was conducted in the United States (Edelman, Brush, Manolova \& Greene 2010), and resulted in findings that the reasons why nascent entrepreneurs want to launch a business are the same across the race, but there are differences in the motivation to grow a new venture between black and white nascent entrepreneurs. Blanchflower and Oswald (1998) conducted a survey in which they found that people who are self-employed reported higher levels of job and life satisfaction than employees.

Numerous comparative studies of entrepreneurs and managers showed that entrepreneurs are moderately higher in achievement motivation than are managers (Stewart \& Roth 2007; Collins, Hanges \& Locke 2004; Begley \& Boyd 1987; Ahmed 1985; Lachman 1980). High level of achievement motivation are consistent with the demands of entrepreneurial role, which appears to attract highly achievementmotivated individuals because of the potential to derive more achievement satisfaction in an entrepreneurial setting, a context that provides the challenge, autonomy, and flexibility for achievement realization (Stewart \& Roth 2007). 
Entrepreneurs are less constrained by organizational systems and structures (Daily et al. 2002) and the entrepreneurial role is less specialized, standardized and formalized. Stewart et al. (1999) discovered that entrepreneurs, who are primarily growth-oriented, were higher in achievement motivation then were managers and "small business owners", which were focused primarily on producing current family income instead of growth, but the "small business owners" were not significantly higher on achievement motivation then managers. The achievement motivation difference between entrepreneurs and managers becomes much more pronounced when the entrepreneur has growth goals or when the entrepreneur is the founder of the venture. Motivation level for venture founders is likely attributable to the circumstances associated with founding. Venture creation appears to present the type of task challenge and lack of routine that attracts very highly motivated individuals (Stewart \& Roth 2007).

\section{EMPIRICAL FINDINGS}

\subsection{Survey and methodology}

This survey was realized in Serbia, during september 2010. Serbia is a landlocked country located at the crossroads of Central and Southeastern Europe, covering the central part of the Balkans. With a GDP for 2010 estimated at $\$ 80$ billion or $\$ 10,897$ per capita, Serbia is an upper-middle income economy by the World Bank. Serbia is also a developing country which is in the middle of the transition process.

SME sector in Serbia is the most profitable segment of economy. During
2006, SMEs participated with $99.7 \%$ in total number of enterprises and with $63 \%$ in total number of employment in Serbia. Also, SMEs facilitated over $40 \%$ of total exporting activities and $60 \%$ of importing activities. This is the reason why SMEs have large importance for successful implementation of transition process, having in mind that economic results of transition are far from expected (Stefanović, Milošević \& Miletić, 2009). When observed through this prism, it is obvious that SMEs are most vital and most rentable part of Serbian economy (Republic Development Bureau, 2008), which is why it is interesting to observe and analyze motivation factors of Serbian entrepreneurs and to discuss its implications on other developing countries.

Using simple random sampling, several thousands of SMEs were selected from all over Serbia and the owners of these enterprises were sent an e-mail containing questionnaire and detailed explanation of the purpose of survey and its benefits, in order to motivate them to participate. In a three weeks period, 82 entrepreneurs answered the survey questions, but three of them were excluded because they were answered in unappropriate manner. Thus, the final sample contained 79 SMEs.

The questionnaire used in this study was originally developed by Hung M. Chu (Chu $\&$ Katsioloudes 2001) and has been used in studies of entrepreneurs across numerous countries, such as: Turkey, Vietnam, Romania, India, Kenya and Ghana (Benzing, Chu \& Kara 2009; Chu, Benzing \& McGee 2007; Benzing \& Chu 2005; Benzing, Chu \& Callanan 2005; Benzing, Chu, \& Szabo 2005). The questionnaire was translated into Serbian and checked for intertranslator consistency. SPSS statistical software was used to process the obtained data. 
The reliability of the survey instrument was satisfactory since the Cronbach's Alpha was relatively high for the motivation items. The Alpha for the motivation variables was 0.7759 .

Five-point Likert scale was used to measure percieved motivation variables: 5 was "extremely important", 4 was "very important", 3 was "mildly important", 2 was "not very important" and 1 was "unimportant". A higher mean score on a variable indicates greater importance.

Factor analysis was used to determine whether motivations variables group together on significant factors. KeiserMeyer-Olkin measure of sampling adequacy (Kaiser, 1970; Kaiser, 1974) and Bartlett's test of Sphericity (Bartlett, 1954) were used to test to establish the justification of factor analysis implementation. Principal component analysis, scree plot and component matrix were used to establish factors. Then, a principal component analysis extraction method with a varimax with Kaiser normalization rotation method was used to determine the factor loading and communalities.

\subsection{Sample characteristics}

As already mentioned, 79 SMEs constitute the sample, out of which only two enterprises can be labeled as medium (65 and 70 employees), which is only $2.53 \%$ of the sample, while 6 of them are in a group of small enterprises $(7.59 \%$ of the sample), and the rest of the sample (71 enterprise) is in a group of micro enterprises (1-9 employees), which is $89.87 \%$ of the sample. Thus, the vast majority of enterprises are micro enterprises.

All organizations in the sample are profit oriented, but the industry structure of sample is very heterogeneous. There are various types of business, such as: manufacturing, service, retail, wholesaling, healthcare, etc.

The age of enterprises are also heterogeneous. The youngest are several months old, while the oldest one is 30 years old. There are 49 enterprises 10 years old or younger $(62.03 \%$ of the sample $), 28$ enterprises between 11 and 20 years of age (36.44\% of the sample) and only 2 enterprises which are older (21 and 30 years of age, which makes $2.53 \%$ of the sample). The average age of enterprises in the sample is 8.61 years.

\subsection{Results for motivation of entrepreneurs}

The questionnaire for motivation of entrepreneurs contained 11 reasons for deciding to own a business. It is already mentioned that the respondents were using five-point Likert scale to give their opinion on importance of each reason for them. The mean and standard deviation for each reason are presented in Table 1.

It was found that the most important reason for deciding to own a business is "To increase my income". This is the same result as in survey of Turkish entrepreneurs (Benzing, Chu \& Kara, 2009), where this reason was also the first one. Given the fact that incomes in Serbia are relatively low when compared with the incomes in countries within region and that purchasing power has decreased, is was quite expected that the desire to increase their incomes would be on the first place of motivation variables. The second and third place are "To be able to use my past experience and training" and "So I will always have a job security" respectively. Serbian economy is struggling with high rate of unemployment 
and the basic implication is that a lot of people think that their expertise would be better put in use if they would have their own business. The other implication is the fear of a losing a job. People need stability and they perceive that owning a business means more secure job. The next four reasons have the mean score higher than 4. Those are: "To prove I can do it", "For my own satisfaction and growth", "To maintain my personal freedom" and "To be my own boss" respectively. All these reasons are implying the need for independency and belief that starting a business may lead to a more quality lifestyle.

Table 1. Mean score and standard deviation for motivation of entrepreneurs in Serbia

\begin{tabular}{|l|r|c|}
\hline \multicolumn{1}{|c|}{ Motivation } & Mean & Std. Deviation \\
\hline 1. To be my own boss & 4.08 & 1.269 \\
\hline 2. To be able to use my past experience and training & 4.58 & 0.691 \\
\hline 3. To prove I can do it & 4.27 & 1.184 \\
\hline 4. To increase my income & 4.63 & 0.701 \\
\hline 5. To provide jobs to family members & 3.18 & 1.551 \\
\hline 6. For my own satisfaction and growth & 4.15 & 1.075 \\
\hline 7. So I will always have job security & 4.56 & 0.780 \\
\hline 8. To build a business to pass on & 3.72 & 1.405 \\
\hline 9. To maintain my personal freedom & 4.14 & 1.174 \\
\hline 10. To be closer to my family & 3.39 & 1.445 \\
\hline 11. To have fun & 2.23 & 1.476 \\
\hline
\end{tabular}

Keiser-Meyer-Olkin measure of sampling adequacy was 0.675 and Bartlett's test of Sphericity was significant at 0.000 . As shown in Table 2, a factor analysis led to four factors, which accounts for 67.115 percent of the cumulative variance. These factors can be interpreted as: greater business achievement factor, independence factor, intrinsic factor and job security factor. These four factors are very similar to those obtained by Benzing, Chu and Kara (2009) in survey of Turkish entrepreneurs. In that study, there were also four factors: security factor, income factor, independence factor and intrinsic factor. While other factors are the same, the only difference is between the "income" factor and the "greater business achievement" factor. But since that under business achievement the income is the first parameter, it can be concluded that these two factors can be viewed as synonyms.

The first factor, reffered as "Greater business achievement", consists of motives: 1, 2, 3, 4 and 9. They imply that entrepreneurs believe that they can achieve more by doing alone then doing for someone else. They are motivated to increase their incomes on their own, in independent manner. This factor explains 20.166 percent of variance. Entrepreneurs appear to believe that independence is very important in a country which is unstable and unpredictable in terms of economic growth and employment. In order to avoid possible downsizing, they are turning to themselves to secure income.

The second factor is reffered to as "Independence factor". It contains motives: 5, 8, 9 and 10. This factor accounts for 17.466 percent of variance. Contemporary entrepreneurs want to be masters of their time. They need to be able to organize their time in the way that suite them. They are also trying to make balance between their proffesional and private life.

The third factor, which is named "Intrinsic factor", consists of variables: 1, 6, 10 and 11. It accounts for 15.458 percent of cumulative variance. This factor explains internal motives of entrepreneurs to start their own business. Entrepreneurs need to prove themselves to their environment and to achieve a significant level of personal satisfaction. 
Table 2. Principal component factor analysis (varimax rotation), factor loadings and communalities for motivation variables

\begin{tabular}{|l|c|c|c|c|c|}
\hline \multicolumn{1}{|c|}{ Motivation } & Factor 1 & Factor 2 & Factor 3 & Factor 4 & Communality \\
\hline 4. To increase my income & 0.800 & & & & 0.655 \\
\hline $\begin{array}{l}\text { 2. To be able to use my past experience and } \\
\text { training }\end{array}$ & 0.745 & & & & 0.607 \\
\hline 1. To be my own boss & 0.694 & & 0.418 & & 0.698 \\
\hline 3. To prove I can do it & 0.502 & & & 0.440 & 0.488 \\
\hline 10. To be closer to my family & & 0.767 & 0.321 & & 0.704 \\
\hline 9. To maintain my personal freedom & 0.434 & 0.752 & & & 0.803 \\
\hline 5. To provide jobs to family members & & 0.603 & & 0.452 & 0.639 \\
\hline 11. To have fun & & & 0.776 & & 0.624 \\
\hline 6. For my own satisfaction and growth & & & 0.764 & & 0.666 \\
\hline 7. So I will always have job security & & & & 0.811 & 0.721 \\
\hline 8. To build a business to pass on & & 0.534 & & 0.610 & 0.778 \\
\hline Variance & 2.218 & 1.921 & 1.700 & 1.543 & \\
\hline Percentage of variance & 20.166 & 17.466 & 15.458 & 14.025 & \\
\hline
\end{tabular}

Finally, "Job security factor" is the forth factor, which contains these variables: $3,5,7$ and 8. This factor accounts for 14.025 percent of cumulative variance. It signifies the importance of workplace security and employment continuity for the family members. Economic unstability forces entrepreneurs to take care of themselves and their families.

\section{DISCUSSION}

Based on the obtained results and their comparison with empirical findings in other countries, which are presented in theoretical part of this paper, it may be concluded that motivational factors of entrepreneurs are generic worldwide (e.g. income factor, family security factor, independence factor, intrinsic factor, etc.), but nevertheless, there are differences which primarily depend on the current situation in local environment.

Research findings of this study are very similar to those obtained by Benzing, Chu and Kara (2009) in survey of Turkish entrepreneurs. In fact, since it was concluded in the previous section that the two seemengly different factors can be treated as synonyms, it may be sad that the same factors are motivating Serbian and Turkish entrepreneurs.

It can be discussed that Serbian entrepreneurs would benefit from a modification of their motivational factors. However this observation might seem unusual (this field is under the domain of cognitive psychology), the modification of motives would probably produce an increase of chances for growth of their SMEs in the marketplace. This modification ought to be directed not in changing current motives, but to add a motive concerned with sustainable development of enterprise in a long-run. Considering that Serbia is a developing country in the economic transition, the lack of such motive can be easily understood. Entrepreneurs are primarily motivated to survive and secure their family members.

On the other hand, Serbian entrepreneurs must be more actively supported by the Serbian government. The development of 
entrepreneurship and SMEs ought to be one of the most important objectives of every country in the world (especially in developing countries, such as Serbia) and ought to have high priority in alocating the budget expenditures. In order to facilitate economic development, it is necessary to make significant improvements in the process of institutionalization of supporting SMEs. This can be achieved by creating environment that will facilitate development of entrepreneurship through numerous stimulating activities, such as: incentives that would facilitate cooperation of SMEs and large enterprises and creation of clusters, establishing organizations for providing assistance to entrepreneurs (e.g. associations of entrepreneurs, government agencies for SMEs development, business incubators, industrial parks, etc.) and providing easy accessible capital.

In order to succeed, SMEs should unit by supporting each other in times of need. This could be accomplished by forming variety of alliances and networks. It would also be mutually beneficial if large businesses and small firms complemented each other in the process of creating goods and services. In that way, SMEs' competitive position could grow strong globally and they could become capable of overcoming barriers and problems to their growth and development. Creation of this kind of environment would foster the development of entrepreneurship in Serbia and would produce an increase in number of successful start-ups.

\section{CONCLUSIONS}

Enterpreneurship and development of SMEs are, without doubt, the future of each country, especially of developing countries.
This is evident, having in mind that two thirds of employees in EU are from SMEs and that $99.8 \%$ of all enterprises are SMEs. This is why entrepreneurship and SMEs are solid foundation for economy growth and development. Because of their size and agility, they also represent the most dynamic and most efficient segment of national economy of any country, regardless of the stage of its economic development.

It is more than ever obvious that, without strong SMEs, it is practically impossible for a country to achieve solid economic position internationally. Because of their distinct entrepreneurial role, they present solid base for improving macro-economic indicators of a country, by attracting direct foreign investments, decreasing unemployment rate, increasing gross added value, exporting activities, etc.

This is why each country ought to define entrepreneurship, as well as creation and support of SMEs, one of its' highest economic priorities. Only by creating highly supportive environment, in which entrepreneurship would thrive, it is possible to increase the rate of successful start-ups which would become major job providers for generations of young people to come. In order to facilitate the creation of such supportive environment, knowledge of the motivational factors of entrepreneurs would be more than welcome. Only if the institutions in charge of creating economic atmosphere are aware of these factors, they can make adequate actions to improve the situation.

This research has continued a serie of research on the topic of motivational factors of entrepreneurs which were conducted in several countries, by using the same methodological approach (Benzing, Chu \& Kara 2009; Chu, Benzing \& McGee 2007; 
Benzing \& Chu 2005; Benzing, Chu \& Callanan 2005; Benzing, Chu, \& Szabo 2005). On he other side, it certainly represents contribution to a small amount of empirical research on this topic in Serbia. The reason for this evident lack of empirical investigations on entrepreneurs may be found in the fact that Serbia is a country which is still in the process of economic and social transition from socialism and highly centralized economy to capitalism and market economy. Socialism did not favour private property and entrepreneurship. Thus, empirical researches, such as this one, are more then welcome to bridge the gap that exists between contemporary theory on entrepreneurship and SMEs on one side and poor practice in Serbia on another side.

\section{References}

Ahmed, S. U. (1985) Nach, Risk-Taking Propensity, Locus of Control and Entrepreneurship, Personality and Individual Differences, 6: 781-782.

Bartlett, M. S. (1954) A Note on the Multiplying Factors for Various Chi-Square Approximations. Journal of the Royal Statistical Society, 16 (Series B): 296-298.

Begley, T. M. \& D. P. Boyd (1987) Psychological Characteristics Associated with Performance in Entrepreneurial Firms and Smaller Businesses, Journal of Business Venturing, 2: 79-93.

Benzing, C. \& H. M. Chu (2005) Entrepreneurial Behavior in Andhra Pradesh, India, Proceedings of the Association of

\title{
МОТИВАЦИОНИ ФАКТОРИ ПРЕДУЗЕТНИКА: ЕМПИРИЈСКИ РЕЗУЛТАТИ ИЗ СРБИЈЕ
}

\author{
Иван Стефановића ${ }^{\mathrm{a}}$, Љубодраг Ранковићб, Слобода Прокић

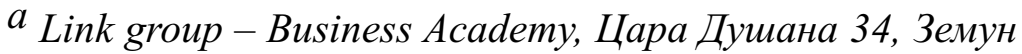 \\ б Кназ Милош, а.д., Јужна индустријска зона бб, Аранђеловач \\ $v^{v}$ Српски економски цуентар, Бранкова 30, Београд
}

Извод

Предузетници имају веома важну улогу у економији сваке земље. Они доприносе развоју националних економија покретањем и вођењем малих и средњих предузећа (МСП), која обично чине више од 95\% укупног броја предузећа и запошљавају више од $60 \%$ радно способног становништва. Значај предузетништва за економски развој обавезује владе земаља и све релевантне институције да наставе да подстичу раст МСП-а свим расположивим средствима. Како би у овоме успеле, све ове институције морају да буду упознате са мотивима предузетника за покретање сопственог бизниса. Са овим циљем су у овом раду представљени резултати емпиријског истраживања мотивационих фактора које је спроведено у Србији. Ово истраживања представља наставак серије истраживања на ову тему која су, коришћењем истоветне методологије, спроведена у одређеном броју земаља.

Кључне речи: Предузетник, МСП, мотивација, фактор, анализа. 
Global Business 2005, Miami Beach, Florida.

Benzing, C., H. M. Chu \& G. Callanan (2005) Regional Comparison of the Motivation and Problems of Vietnamese Entrepreneurs, Journal of Developmental Entrepreneurship, 10: 3-27.

Benzing, C., H. M. Chu \& O. Kara (2009) Entrepreneurs in Turkey: A Factor Analysis of Motivations, Success Factors and Problems, Journal of Small Business Management, 47(1): 58-91.

Benzing, C., H. M. Chu \& B. Szabo (2005) Hungarian and Romanian Entrepreneurs in Romania - Motivation, Problems and Differences, Journal of Global Business, 16: 77-87.

Bewayo, E. D. (1995) Uganda Entrepreneurs: Why Are They in Business?, Journal of Small Business Strategy, 6: 67-78.

Blanchflower, D. G. \& A. J. Oswald (1998) What Makes an Entrepreneur?, Journal of Labor Economics, 16(1): 26-60.

Chu, H. M., C. Benzing \& C. McGee (2007) Ghanaian and Kenyan Entrepreneurs: A Comparative Analysis of Their Motivations, Success Characteristics, and Problems, Journal of Development Entrepreneurship, 12(3): 295-322.

Chu, H. M. \& M. I. Katsioloudes (2001) Cultural Context in the VietnameseAmerican Entrepreneurial Experience, Journal of Transmisional Development, 7(2): 37-46.

Collins, C. J., P. J. Hanges \& E. A. Locke (2004) The Relationship of Achievement Motivation to Entrepreneurial Behavior: A Meta-Analysis, Human Performance, 17(1): 95-117.

Daily, C. M., P. P. McDougall, J. G. Covin \& D. R. Dalton (2002) Governance and Strategic Leadership in Entrepreneurial Firms, Journal of Management, 28: 387-412.
Edelman, L. F., C. G. Brush, T. S. Manolova \& P. G. Greene (2010) Start-up Motivations and Growth Intentions of Minority Nascent Entrepreneurs, Journal of Small Buusiness Management, 48(2): 174196.

Evans, G. H., Jr. (1942) A Theory of Entrepreneurship, The Journal of Economic History, 2, December, 142-146.

Jiangyong, L. \& Z. Tao (2008) Determinants of Entrepreneurial Activities in China, Journal of Business Venturing (Article in Press, DOI: 10.1016/j.busvent.2008.10.005)

Jones, V. M. \& N. Nummela (2008) International Entrepreneurship: Expanding the Domain and Extending Our Research Questions, European Management Journal, 26: 349-353.

Kaiser, H. (1970) A Second Generation Little Giffy. Psychometrika, 35: 401-415.

Kaiser, H. (1974) An Index of Factorial Simplicity. Psychometrika, 39: 31-36.

Kuratko, D.F., J.S. Hornsby \& D.W. Naffziger (1997) An Examination of Owners' Goals in Sustaining Entrepreneurship, Journal of Small Business Management, 35(1): 24-33.

Lachman, R. (1980) Toward Measurement of Entrepreneurial Tendencies, Management International Review, 20(2): 108-116.

Ozsoy, O., D. Oksoy \& K. Kozan (2001) The Characteristics of Turkish Entrepreneurs and Their Enterprises. Long Island, NY: College of Business, Alfred University.

Republic Development Bureau (2008) Report on Serbia's Development in 2007. Belgrade: Republic Development Bureau (in Serbian).

Robichaud, Y., E. McGraw \& A. Roger (2001) Toward the Development of a Measuring Instrument for Entrepreneurial 
Motivation, Journal of Developmental Entrepreneurship, 6(1): 189-202.

Roy, M.A. \& D. Wheeler (2006) A Survey of Micro-Enterprise in Urban West Africa: Drivers Shaping the Sector, Development in Practice, 16(5): 452-464.

Schmiemann, M. (2008) Enterprises by Size and Class: Overview of SMEs in the EU. Statistics in Focus, 31, Luxembourg: Eurostat.

Schumpeter, J. A. (1934) The Theory of Economic Development. Cambridge, MA.: Harvard University Press.

Stefanović, I., D. Milošević \& S. Miletić (2009) Significance and Development Problems of SMEs in Contemporary Market Economy, Serbian Journal of Management, 4(1): 127-136.

Stewart, W. H., Jr. \& P. L. Roth (2007) A Meta-Analysis of Achievement Motivation Differences between Entrepreneurs and Managers, Journal of Small Business Management, 45(4): 401-421.

Stewart, W. H., Jr., W. E. Watson, J. A. Carland \& J. W. Carland (1999) A Proclivity for Entrepreneurship: A Comparison of Entrepreneurs, Small Business Owners, and Corporate Managers, Journal of Business Venturing, 14: 189-214.

Swierczek, F. \& T. T. Ha (2003) Motivation, Entrepreneurship, and Performance of SMEs in Vietnam, Journal of Enterprise Culture, 11(1): 47-68. van Praag, C. M. \& J. S. Cramer (2001) The Roots of Entrepreneurship and Labour Demand: Individual Ability and Low Risk Aversion, Economica, New Series, 68(269): 45-62.

Živković, Ž., I. Mihajlović. \& S. Prvulović (2009) Developing Motivation Model as a Strategy for HRM in Small Enterprises Under Transitional Economy. Serbian Journal of Management, 4(1): 1-27.
Żivković, Ż. \& D. Żivković (2009) Determinants of Entrepreneurial Activities in Serbia, Entrepreneurship \& Innovation Journal, 1(1): 162-174. 